\title{
Stability of Epinephrine at Standard Concentrations
}

\author{
Roxane R Carr, Diane Decarie, and Mary H H Ensom
}

\begin{abstract}
Background: To minimize medication errors, standard concentrations are recommended for medications intended for continuous infusion in pediatric patients. Premixing of epinephrine (commonly used to manage septic shock in children) would improve timeliness, safety, and costeffectiveness. However, information about the stability of epinephrine at standard concentrations is limited.
\end{abstract}

Objectives: To evaluate the stability of epinephrine in 5\% dextrose in water at standard concentrations and to extend its expiration date after storage in infusion bags at $4^{\circ} \mathrm{C}$ and $25^{\circ} \mathrm{C}$ for up to 30 days.

Methods: A total of 6 infusion bags were prepared with $200 \mathrm{~mL}$ of epinephrine solution, 2 bags for each of 3 standard concentrations (25, 50 , and $100 \mu \mathrm{g} / \mathrm{mL}$ ). Three bags (one for each concentration) were stored under refrigeration $\left(4^{\circ} \mathrm{C}\right)$, and the remaining 3 bags were stored at room temperature $\left(25^{\circ} \mathrm{C}\right.$ ). Physical characteristics (including $\mathrm{pH}$, colour, and presence of precipitate) were evaluated daily for the first 14 days and every 1 to 5 days thereafter until day 30. Three $1.5-\mathrm{mL}$ samples were collected from each bag immediately after preparation (time 0), every $24 \mathrm{~h}$ (at $24 \mathrm{~h}, 48 \mathrm{~h}, 72 \mathrm{~h}, 96 \mathrm{~h}$, etc.) for the first 14 days, and every 1 to 5 days thereafter until day 30 . Each sample was analyzed by stability-indicating high-performance liquid chromatography. A solution was considered stable if it maintained at least $90 \%$ of its initial concentration.

Results: No notable changes in $\mathrm{pH}$, colour, or precipitation were observed in any of the solutions after storage at $4^{\circ} \mathrm{C}$ or $25^{\circ} \mathrm{C}$ for up to 30 days. All formulations maintained more than $95 \%$ of the initial epinephrine concentration on day 30. In addition, the calculated lower limit of the $95 \%$ confidence interval indicated that $93 \%$ or more of the initial concentration remained on day 30 .

Conclusions: Preparations of epinephrine were stable for up to 30 days, with or without refrigeration. Because stability alone does not guarantee bioavailability or efficacy of a drug, future clinical studies are recommended to evaluate the pharmacokinetics and pharmacodynamics of these formulations.

Keywords: epinephrine, standard concentration, stability

\section{RÉSUMÉ}

Contexte : Afin de réduire au maximum les erreurs de médication, il est recommandé d'utiliser des concentrations standards pour les médicaments administrés par perfusion continue aux enfants. La préparation préalable des solutions d'épinéphrine (couramment utilisée pour traiter le choc septique chez l'enfant) permettrait d'améliorer la rapidité d'action, la sécurité et le rapport coût-efficacité. Il existe malheureusement peu de données portant sur la stabilité de solutions d'épinéphrine de concentrations standards.

Objectifs : Évaluer la stabilité de l'épinéphrine de concentrations standards dans du dextrose à $5 \%$ dans l'eau et augmenter la durée de conservation des solutions entreposées dans des sacs pour perfusion à $4{ }^{\circ} \mathrm{C}$ et à $25^{\circ} \mathrm{C}$ jusqu’à 30 jours.

Méthodes : Six sacs pour perfusion contenant $200 \mathrm{~mL}$ d'une solution d'épinéphrine ont été préparés, soit une paire de chacune des trois concentrations standards $(25,50$ et $100 \mu \mathrm{g} / \mathrm{mL})$. Trois sacs ont été conservés au réfrigérateur $\left(4^{\circ} \mathrm{C}\right)$ et les trois autres ont été entreposés à la température ambiante $\left(25^{\circ} \mathrm{C}\right)$. Les propriétés physiques (notamment le $\mathrm{pH}$, la couleur et la présence de précipité) ont été évaluées quotidiennement les 14 premiers jours, puis à des intervalles de 1 à 5 jours jusqu'au jour 30 . Trois échantillons de $1,5 \mathrm{~mL}$ ont été recueillis de chaque sac immédiatement après la préparation de la solution (temps 0), puis toutes les 24 heures ( $24 \mathrm{~h}, 48 \mathrm{~h}, 72 \mathrm{~h}, 96 \mathrm{~h}$, etc.) pendant les 14 premiers jours et ensuite à des intervalles de 1 à 5 jours jusqu'à la fin de la période de 30 jours. Chaque échantillon a été analysé à l'aide d'une épreuve mesurant la stabilité par chromatographie liquide haute performance. Une solution était considérée comme stable si elle conservait au moins $90 \%$ de sa concentration initiale.

Résultats : Aucun précipité et aucun changement notable du $\mathrm{pH}$ ou de la couleur n'ont été observés dans l'ensemble des solutions après un entreposage à $4{ }^{\circ} \mathrm{C}$ ou à $25^{\circ} \mathrm{C}$ d'une période de 30 jours. Toutes les préparations avaient conservé plus de $95 \%$ des concentrations initiales d'épinéphrine au jour 30. De plus, la limite inférieure de l'intervalle de confiance à $95 \%$ indiquait que les préparations avaient conservé $93 \%$ ou plus de leurs concentrations initiales au jour 30 .

Conclusions : Les préparations d'épinéphrine sont demeurées stables pendant les 30 jours, qu'elles aient été réfrigérées ou non. Comme la stabilité seule ne garantit pas la biodisponibilité ou l'efficacité d'un médicament, d'autres études cliniques sont recommandées afin d'évaluer le comportement pharmacocinétique et pharmacodynamique de ces préparations.

Mots clés : épinéphrine, concentration standard, stabilité

[Traduction par l'éditeur] 


\section{INTRODUCTION}

$\mathrm{M}$

edication safety standards have recommended the use of standard concentrations of IV medications intended for continuous infusion in pediatric patients. ${ }^{1}$ This recommendation is intended to decrease errors associated with dose and concentration calculations for medications that have been associated with harm to patients when administered at high doses (high-alert drugs). ${ }^{2-4}$ Epinephrine administered via continuous infusion is commonly used to manage septic shock in children. ${ }^{5}$ To allow timely and safe administration, it is desirable to have epinephrine available in critical patient care areas in premixed, "ready-to-administer" standard concentrations. ${ }^{3,4}$ Furthermore, the ability of an institution's pharmacy department to premix the medication in batches, with an expiry date that minimizes medication wastage, is cost-effective in terms of both labour and materials. However, limited information regarding the stability of IV epinephrine at standard concentrations has made it difficult to adopt this approach.

At the time of the study reported here, 3 concentrations of epinephrine $(25 \mu \mathrm{g} / \mathrm{mL}, 50 \mu \mathrm{g} / \mathrm{mL}$, and $100 \mu \mathrm{g} / \mathrm{mL}$ in $5 \%$ dextrose in water $[\mathrm{D} 5 \mathrm{~W}])$ were being used at the authors' institution for continuous infusions in children and babies requiring vasopressor support. The available literature suggested a stability of 24 to $84 \mathrm{~h}$, depending on the concentration. ${ }^{6-8}$ However, a single bag of medication run as a continuous infusion is hung for a maximum of $96 \mathrm{~h}$ (at which point the IV tubing must be changed for infection control purposes). The available stability data did not allow for premixed batching of these concentrations, which slowed turnaround times when the medication was ordered and decreased efficiency and costeffectiveness in the pharmacy department (as drug preparation is less efficient and less cost-effective if batches of standard concentrations cannot be prepared in advance). The purpose of this study was to evaluate the stability of epinephrine IV in D5W and to extend its expiration date after storage in infusion bags at $4^{\circ} \mathrm{C}$ and $25^{\circ} \mathrm{C}$ for up to 30 days. It was anticipated that if the drug was shown to be stable for longer than $84 \mathrm{~h}$, patient care would be improved and costs would be reduced, through elimination of problems associated with delayed initiation of potentially life-saving medication (caused by the delay in preparation time).

\section{METHODS}

\section{Preparation of Epinephrine}

Stock solutions of epinephrine were prepared from a commercially available $1 \mathrm{mg} / \mathrm{mL}$ solution (Hospira, SaintLaurent, Quebec; lot 368188E01), diluted in D5W (Baxter Corporation, Mississauga, Ontario; lot W3D23A1) to concentrations of 25,50 , and $100 \mu \mathrm{g} / \mathrm{mL}$, and transferred to empty
500-mL sterile infusion bags (IntraVia Container, Baxter Healthcare Corporation, Deerfield, Illinois; lot UR300137). A total of 6 infusion bags were prepared, 2 bags for each of the 3 standard concentrations. Three bags (one for each concentration) were stored under refrigeration $\left(4^{\circ} \mathrm{C}\right)$, and the remaining 3 bags were stored at room temperature $\left(25^{\circ} \mathrm{C}\right)$. All of the bags were kept in the dark.

The physical characteristics of the solutions were evaluated qualitatively at the time of preparation, every day for the first 14 days, and every 1 to 5 days thereafter until day 30. More specifically, the physical characteristics of each solution were evaluated by the same individual (R.C.), including visual examination for changes in colour (against white and black backgrounds) and for formation of precipitate. The infusion bags stored at $4^{\circ} \mathrm{C}$ were allowed to equilibrate to $25^{\circ} \mathrm{C}$. Three aliquots were collected from each bag for determination of $\mathrm{pH}$. The pH meter (model 8000, VWR Canlab, Mississauga, Ontario) was calibrated with commercially available standards at the beginning of each testing session. Immediately after the physical observations, samples $(1.5 \mathrm{~mL})$ were transferred to 2-mL polypropylene vials (VWR, Edmonton, Alberta; lot 10809978) and immediately stored at $-85^{\circ} \mathrm{C}$, where they were kept for up to 3 months, until analysis by a stability-indicating high-performance liquid chromatography (HPLC) - ultraviolet detection method.

\section{Preparation of Stock Solutions, Standards, and Standard Curve}

Standards were prepared by diluting epinephrine $1 \mathrm{mg} / \mathrm{mL}$ (Hospira, Saint-Laurent, Quebec; lot 368188E01) in HPLCgrade water to concentrations of 20, 50, 100, 150, and 200 $\mu \mathrm{g} / \mathrm{mL}$ to construct the standard curve. The internal standard was prepared by dilution of locally prepared dopamine $3200 \mu \mathrm{g} / \mathrm{mL}$ (BC Children's and Women's Hospital; lot XX50605) in HPLC-grade water to a concentration of 250 $\mu \mathrm{g} / \mathrm{mL}$. Standards were prepared by combining $0.5 \mathrm{~mL}$ of each stock solution and $0.5 \mathrm{~mL}$ dopamine $250 \mu \mathrm{g} / \mathrm{mL}$. The final concentrations of epinephrine in the standard samples injected onto the chromatograph were $10,25,50,75$, and $100 \mu \mathrm{g} / \mathrm{mL}$, and the final concentration of internal standard (dopamine) was $125 \mu \mathrm{g} / \mathrm{mL}$. These dilutions yielded optimal chromatographic characteristics. All standards were passed through a 0.45- $\mu \mathrm{m}$ microfilter (Acrodisc GHP syringe filter, Gelman, Ann Arbor, Michigan; lot A10647284) to prevent injection of impurities onto the column.

A 5-point calibration curve was prepared, with a blank (water only) at the beginning of each run, to ensure no carryover from one run to the next. The range of this calibration curve (10 to $100 \mu \mathrm{g} / \mathrm{mL}$ ) encompassed the test concentrations of epinephrine $(25,50$, and $100 \mu \mathrm{g} / \mathrm{mL})$. The calibration curve was generated by least-squares regression of the peak area ratio 
of epinephrine to dopamine (the internal standard) and the concentration of each epinephrine standard. The precision of the assay was evaluated by intraday and interday validation methods. The intraday variability was determined by running stock solutions of epinephrine at concentrations of 10,50, and $100 \mu \mathrm{g} / \mathrm{mL}$ in quadruplicate throughout a single day. The interday variability was determined by running the same analyte concentrations in quadruplicate daily for 4 days. The means, standard deviations (SDs), and coefficients of variation were then calculated. Acceptable limits for the coefficients of variation were defined a priori as less than $10 \%$.

\section{Preparation of Samples}

On the day of analysis, epinephrine study samples were thawed and mixed by vortex mixer for $10 \mathrm{~s}$. A $0.5-\mathrm{mL}$ aliquot was withdrawn from each study sample and diluted with $0.5 \mathrm{~mL}$ of internal standard (dopamine $250 \mu \mathrm{g} / \mathrm{mL}$ ). The theoretical final concentrations of epinephrine were 12.5, 25, and $50 \mu \mathrm{g} / \mathrm{mL}$ Each sample was passed through a $0.45-\mu \mathrm{m}$ microfilter before withdrawal of a $25-\mu \mathrm{L}$ sample for injection onto the column. A single assay was performed on each sample.

\section{HPLC Instrumentation}

The HPLC instrumentation (Waters Alliance System model 2690, Waters Ltd, Mississauga, Ontario) consisted of a delivery pump, an automatic injector equipped with a $200-\mu \mathrm{L}$ injector, an Atlantis dC18 $4.6 \mathrm{~mm} \times 150 \mathrm{~mm}$ column (Waters Ltd; lot 01283621310207), an Atlantis dC18 $3.9 \mathrm{~mm} \times$ $20 \mathrm{~mm}$ guard column (Waters Ltd; lot 0128363171), and an ultraviolet detector set at $280 \mathrm{~nm}$ (model 2487 dual-wavelength absorbance detector, Waters Ltd). The mobile phase consisted of an 88:2:10 (v/v/v) mixture of water (Fisher Scientific, Richmond, British Columbia; lot 055941), acetonitrile (Fisher Scientific; lot 81062), and a $100 \mathrm{mmol} / \mathrm{L}$ solution of ammonium acetate $\left(\mathrm{C}_{2} \mathrm{H}_{7} \mathrm{NO}_{2}\right)$ (Sigma-Aldrich, Oakville, Ontario; lot 026K06687), pH 5.0. All solvents were HPLC-grade and were filtered before use. The flow rate was set at $1.2 \mathrm{~mL} / \mathrm{min}$.

\section{Accelerated Degradation of Epinephrine}

Epinephrine $100 \mu \mathrm{g} / \mathrm{mL}$ was prepared from epinephrine $1 \mathrm{mg} / \mathrm{mL}$. The $\mathrm{pH}$ was adjusted to 9.0 with $0.1 \mathrm{~N}$ sodium hydroxide $(\mathrm{NaOH})$ (Fisher Scientific; lot SC9105042) and the sample was incubated for $4 \mathrm{~h}$ at $60^{\circ} \mathrm{C}$. The sample was cooled to room temperature and the $\mathrm{pH}$ readjusted to 3.6 with $1 \mathrm{~N}$ hydrochloric acid (HCl) (Fisher Scientific; lot 299067). The sample was then adjusted with water to a final concentration of $25 \mu \mathrm{g} / \mathrm{mL}$ and filtered, and a sample of $25 \mu \mathrm{L}$ was injected onto the column. The chromatogram obtained for the degraded preparation was compared with a chromatogram obtained from a standard with concentration $25 \mu \mathrm{g} / \mathrm{mL}$ to determine any changes in concentration, retention time, and peak shape.

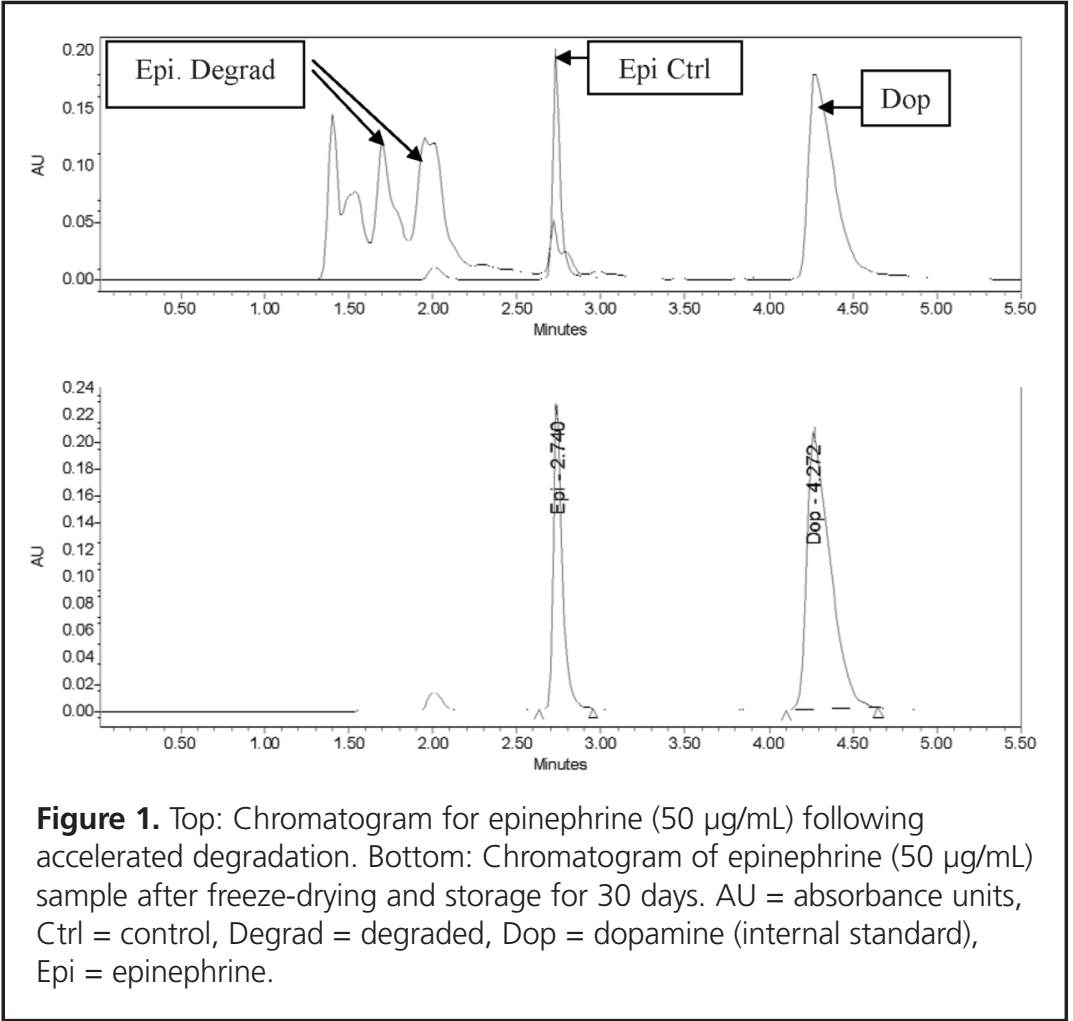


Table 1. Measured pH of Solutions of Epinephrine Stored at $25^{\circ} \mathrm{C}$ or $4^{\circ} \mathrm{C}$ (Mean \pm Standard Deviation)

\begin{tabular}{lcc} 
Concentration & $\mathbf{2 5}^{\circ} \mathrm{C}$ & $\mathbf{4}^{\circ} \mathrm{C}$ \\
\hline $25 \mu \mathrm{g} / \mathrm{mL}$ & $3.45 \pm 0.18$ & $3.51 \pm 0.18$ \\
\hline $50 \mu \mathrm{g} / \mathrm{mL}$ & $3.48 \pm 0.17$ & $3.53 \pm 0.14$ \\
\hline $100 \mu \mathrm{g} / \mathrm{mL}$ & $3.49 \pm 0.13$ & $3.52 \pm 0.11$ \\
\hline
\end{tabular}

\section{Statistical Analysis}

The means, SDs, and coefficients of variation were calculated for samples analyzed in triplicate (experimental samples) or quadruplicate (standards). For each study day, the percentage of initial epinephrine concentration remaining was calculated for each sample. The percentage of epinephrine remaining on day 30 was calculated from the concentration measured on day 30, as determined by linear regression and concentration observed on day 0 , according to the following formula: concentration on day $30 \div$ concentration on day 0 $\times 100$. The $95 \%$ confidence interval (CI) of the amount remaining on day 30 was calculated from the lower limit of the 95\% CI of the slope of the curve relating concentration to time, determined by linear regression, via computer analysis
(SPSS 12.0 for Windows, SPSS Inc, Chicago, Illinois), according to the following formula: lower limit of the $95 \% \mathrm{CI}$ of the concentration on day $30 \div$ concentration on day $0 \times 100 \%$. Stability was defined as maintenance of at least $90 \%$ of the initial epinephrine concentration.

\section{RESULTS}

For the standard curve generated, regression analysis of the peak area ratio of epinephrine (standards) to internal standard versus concentration demonstrated linearity over the working range of the standard concentrations, with coefficients of determination $\left(r^{2}\right)$ greater than $0.997(n=4)$. The intraday $(n=4)$ and interday $(n=4)$ coefficients of variation for the 3 different concentrations of standards were within acceptable limits (i.e., < 10\%): 3.07\% and 6.72\%, respectively, for the 10 $\mu \mathrm{g} / \mathrm{mL}$ solution; $0.41 \%$ and $2.53 \%$, respectively, for the 50 $\mu \mathrm{g} / \mathrm{mL}$ solution; and $0.21 \%$ and $1.33 \%$, respectively, for the $100 \mu \mathrm{g} / \mathrm{mL}$ solution. The retention time for epinephrine was $2.75 \mathrm{~min}$, whereas the retention time for the internal standard (dopamine) was $4.4 \mathrm{~min}$. When epinephrine was subjected to degradation, degradation peaks appeared between 1.4 and $2.2 \mathrm{~min}$, and a much smaller peak of epinephrine $(27.6 \%$ of
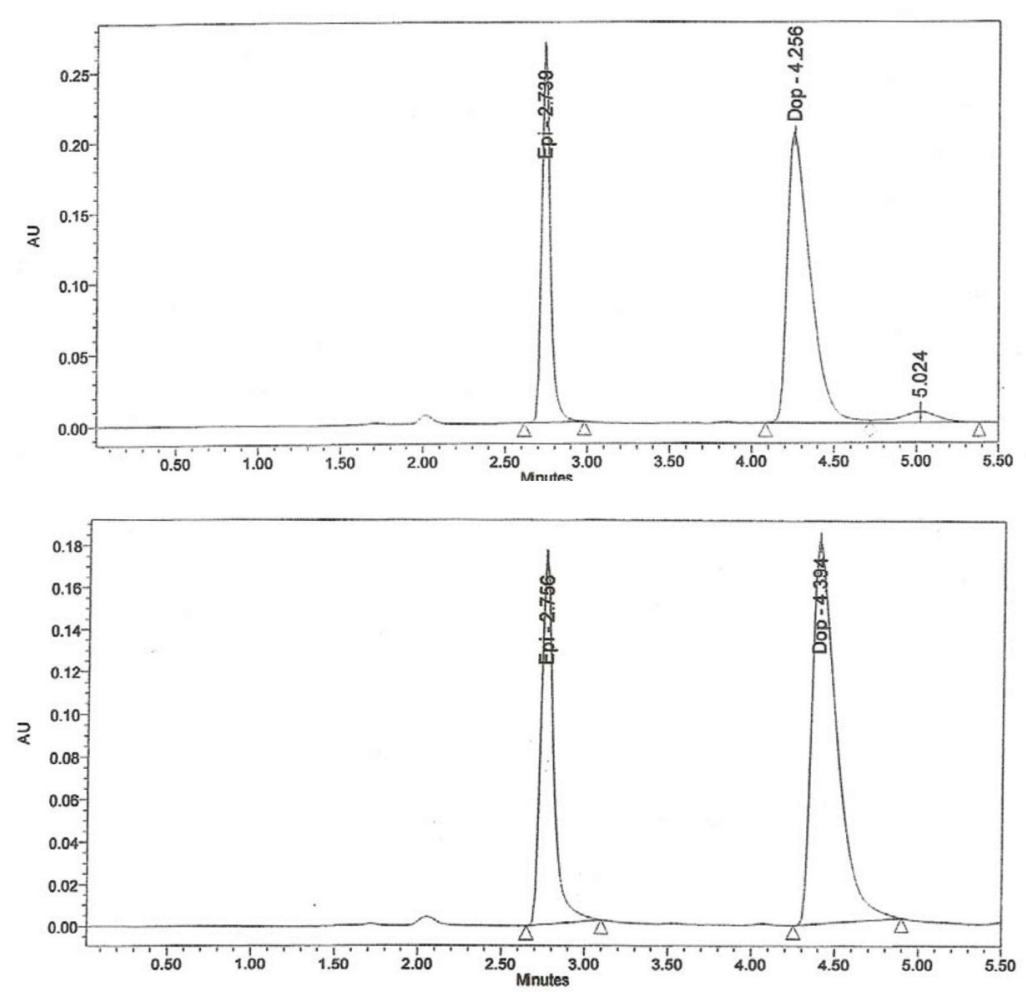

Figure 2. Chromatograms for epinephrine $(50 \mu \mathrm{g} / \mathrm{mL})$ on day 0 (top) and after 30 days of storage at $25^{\circ} \mathrm{C}$ (bottom). $\mathrm{AU}=$ absorbance units, Dop $=$ dopamine (internal standard), Epi = epinephrine. 


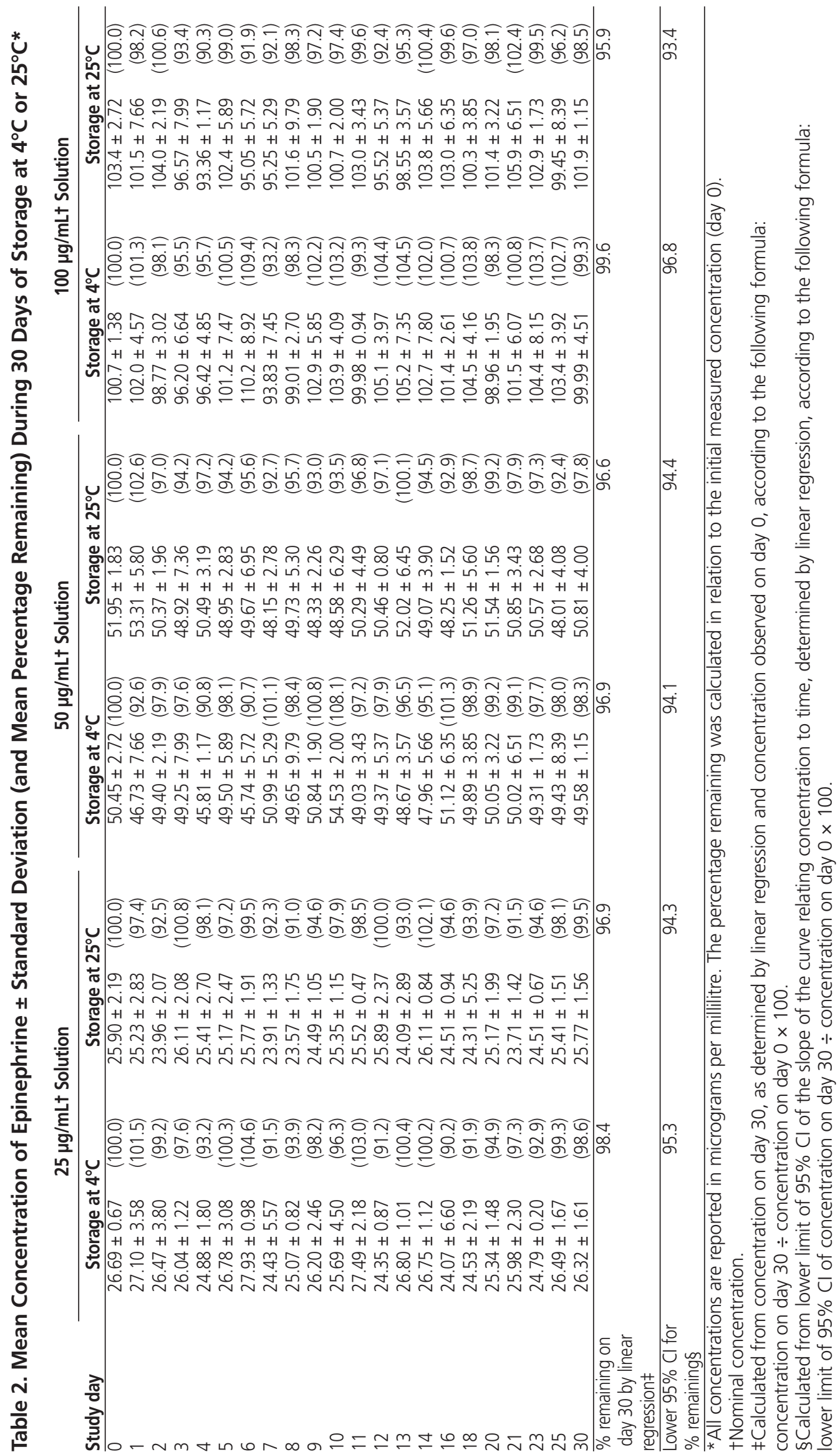


original concentration) was observed at $2.73 \mathrm{~min}$ (Figure 1). Thus, the HPLC method was deemed capable of indicating stability.

Each solution remained clear and presented no notable changes in physical appearance or colour over the study period of 30 days. No significant fluctuations in $\mathrm{pH}$ were observed (Table 1).

The HPLC analysis showed that, at both storage temperatures, solutions of epinephrine at 25, 50, and 100 $\mu \mathrm{g} / \mathrm{mL}$ maintained between $90 \%$ and $109 \%$ of their initial concentrations on every study day (Figure 2, Table 2). Furthermore, more than $95 \%$ of the initial epinephrine concentration remained on day 30, according to linear regression analysis of the concentration-time data. Similarly, the calculated lower limit of the $95 \%$ CI indicated that at least $93 \%$ of the initial concentration remained on day 30 (Table 2).

\section{DISCUSSION}

No notable changes in $\mathrm{pH}$ or colour were observed in solutions after storage at either $4^{\circ} \mathrm{C}$ or $25^{\circ} \mathrm{C}$ for up to 30 days. All concentrations of epinephrine maintained at least $90 \%$ of initial concentration at both temperatures. A limitation of the study design related to the freezing of samples at $-85^{\circ} \mathrm{C}$ until the time of batch analysis. It was assumed that epinephrine would not degrade at this low temperature and that no volume losses would occur because of freeze-drying during storage. In addition, it was assumed that errors due to serial analysis would have been greater than any errors occurring with batch analysis. In vitro determination of stability of a preparation does not automatically guarantee that pharmacokinetics and pharmacodynamics will remain unchanged in vivo. Ideally, follow-up pharmacokinetic and pharmacodynamic studies should be performed. In addition, sterility was not tested; however, the infusion bags used were sterile, and the solutions were prepared in a sterile environment.

\section{CONCLUSION}

According to qualitative, $\mathrm{pH}$, and HPLC analysis of samples obtained over a 30-day period, epinephrine solutions at 25,50 , and $100 \mu \mathrm{g} / \mathrm{mL}$ stored in infusion bags at either $4^{\circ} \mathrm{C}$ or $25^{\circ} \mathrm{C}$ were stable, maintaining at least $90 \%$ of their original concentrations, for up to 30 days. The results of this study provide information on extending the expiry date of epinephrine solutions.

\section{References}

1. Medication management standards. Ottawa $(\mathrm{ON})$ : Accreditation Canada; [cited 2014 May 26]. Available from: www.accreditation.ca/medicationmanagement-standards

2. Rich DS. New JCAHO medication management standards for 2004. Am J Health Syst Pharm. 2004;61(13):1349-58.

3. Apkon M, Leonard J, Probst L, DeLizio L, Vitale R. Design of a safer approach to intravenous drug infusions: failure mode effects analysis. Qual Saf Health Care. 2004;13(4):265-71.

4. Bell DS, Clements RS Jr, Perentesis G, Roddam R, Wagenknecht L. Dosage accuracy of self-mixed vs premixed insulin. Arch Int Med. 1991;151(11):2265-9.

5. Dellinger RP, Levy MM, Rhodes A, Annane D, Gerlach H, Opal SM, et al. Surviving Sepsis Campaign: international guidelines for management of severe sepsis and septic shock, 2012. Intensive Care Med. 2013;39(2):165-228.

6. Ghanayem NS, Yee L, Nelson T, Wong S, Gordon JB, Marcdante K, et al. Stability of dopamine and epinephrine solutions up to 84 hours. Pediatr Crit Care Med. 2001;2(4):315-7.

7. Allwood MC. The stability of four catecholamines in $5 \%$ glucose infusions. $J$ Clin Pharm Ther. 1991;16(5):337-40.

8. Peddicord TE, Olsen KM, Zumbrunnen TL, Warner DJ, Webb L. Stability of high-concentration dopamine hydrochloride, norepinephrine bitartrate, epinephrine hydrochloride, and nitroglycerin in 5\% dextrose injection. $\mathrm{Am} J$ Health Syst Pharm. 1997;54(12):1417-9.

Roxane $\mathbf{R}$ Carr, BSC(Pharm), ACPR, PharmD, FCSHP, BCPS, is Clinical Coordinator in the Department of Pharmacy, Children's and Women's Health Centre of British Columbia, and Assistant Professor, part-time, with the Faculty of Pharmaceutical Sciences, The University of British Columbia, Vancouver, British Columbia.

Diane Decarie, BSc, is a Research Consultant with the Department of Pharmacy, Children's and Women's Health Centre of British Columbia, Vancouver, British Columbia.

Mary H H Ensom, PharmD, FASHP, FCCP, FCSHP, FCAHS, is Professor with the Faculty of Pharmaceutical Sciences and Distinguished University Scholar, The University of British Columbia, and Clinical Pharmacy Specialist, Children's and Women's Health Centre of British Columbia, Vancouver, British Columbia. She is also the Editor of the CJHP.

Competing interests: None declared.

Address correspondence to:

Dr Roxane R Carr

Pharmacy Department

Children's and Women's Health Centre of British Columbia

4500 Oak Street, Room OB7

Vancouver BC V6H 3N1

e-mail: rcarr@cw.bc.ca

Acknowledgement

The study was supported by the Medbuy Corporation Endowment Fund. 